einstein

Official Publication of the Instituto Israelita

de Ensino e Pesquisa Albert Einstein

ISSN: 1679-4508 | e-ISSN: 2317-6385
How to cite this article:

Rodrigues IC, Kaasi A, Maciel Filho R,

Jardini AL, Gabriel LP. Cardiac tissue

engineering: current state-of-the-art

materials, cells and tissue formation. einstein (São Paulo). 2018:16(3):eRB4538.

https://doi.org/10.1590/S1679-45082018RB4538

Corresponding author:

Laís Pellizzer Gabriel

Rua Pedro Zaccaria, 1,300, Jardim

Santa Luzia - Zip code: 13484-350

Limeira, SP, Brazil - Phone: (55 19) 3701-6744

E-mail: lais.gabriel@fca.unicamp.br

Received on:

Apr 22, 2018

\section{Accepted on:}

July 24, 2018

\section{Copyright 2018}

\section{(c) By}

This content is licensed

under a Creative Commons

Attribution 4.0 International License.
REVIEWING BASIC SCIENCES

\section{Cardiac tissue engineering:}

\section{current state-of-the-art materials, cells and tissue formation}

\section{Engenharia de tecidos cardíacos: atual estado da arte a respeito de materiais, células e formação tecidual}

\author{
Isabella Caroline Pereira Rodrigues ${ }^{1}$, Andreas Kaasi², Rubens Maciel Filho ${ }^{3}$, \\ André Luiz Jardini', Laís Pellizzer Gabriel' \\ ${ }^{1}$ Faculdade de Ciências Aplicadas, Universidade Estadual de Campinas, Limeira, SP, Brazil. \\ 2 Eva Scientific Ltda, São Paulo, SP, Brazil. \\ ${ }^{3}$ Instituto Nacional de Ciência e Tecnologia em Biofabricação, Campinas, SP, Brazil.
}

DOI: 10.1590/S1679-45082018RB4538

\section{ABSTRACT}

Cardiovascular diseases are the major cause of death worldwide. The heart has limited capacity of regeneration, therefore, transplantation is the only solution in some cases despite presenting many disadvantages. Tissue engineering has been considered the ideal strategy for regenerative medicine in cardiology. It is an interdisciplinary field combining many techniques that aim to maintain, regenerate or replace a tissue or organ. The main approach of cardiac tissue engineering is to create cardiac grafts, either whole heart substitutes or tissues that can be efficiently implanted in the organism, regenerating the tissue and giving rise to a fully functional heart, without causing side effects, such as immunogenicity. In this review, we systematically present and compare the techniques that have drawn the most attention in this field and that generally have focused on four important issues: the scaffold material selection, the scaffold material production, cellular selection and in vitro cell culture. Many studies used several techniques that are herein presented, including biopolymers, decellularization and bioreactors, and made significant advances, either seeking a graft or an entire bioartificial heart. However, much work remains to better understand and improve existing techniques, to develop robust, efficient and efficacious methods.

Keywords: Biopolymers; Bioreactors; Heart transplantation; Cardiomyoplasty; Cardiovascular diseases; Tissue engineering

\section{RESUMO}

Doenças cardiovasculares são responsáveis pelo maior número de mortes no mundo. 0 coração possui capacidade de regeneração limitada, e o transplante, por consequência, representa a única solução em alguns casos, apresentando várias desvantagens. A engenharia de tecidos tem sido considerada a estratégia ideal para a medicina cardíaca regenerativa. Trata-se de uma área interdisciplinar, que combina muitas técnicas as quais buscam manter, regenerar ou substituir um tecido ou órgão. A abordagem principal da engenharia de tecidos cardíacos é criar enxertos cardíacos, sejam substitutos do coração inteiro ou de tecidos que podem ser implantados de forma eficiente no organismo, regenerando o tecido e dando origem a um coração completamente funcional, sem desencadear efeitos colaterais, como imunogenicidade. Nesta revisão, apresentase e compara-se sistematicamente as técnicas que ganharam mais atenção nesta área e que geralmente focam em quatro assuntos importantes: seleção do material a ser utilizado como enxerto, produção do material, seleção das células e cultura de células in vitro. Muitos estudos, fazendo uso de várias das técnicas aqui apresentadas, incluindo biopolímeros, descelularização e 
biorreatores, têm apresentado avanços significativos, seja para obter um enxerto ou um coração bioartifical inteiro. No entanto, ainda resta um grande esforço para entender e melhorar as técnicas existentes, para desenvolver métodos robustos, eficientes e eficazes.

Descritores: Biopolímeros; Reatores biológicos; Transplante de coração; Cardiomioplastia; Doenças cardiovasculares; Engenharia tecidual

\section{INTRODUCTION}

Cardiovascular diseases are the leading cause of death in the world. In 2015, World Health Organization (WHO) estimated that 17.7 million people died from cardiovascular diseases, accounting for $31 \%$ of deaths worldwide $\left({ }^{(1)}\right.$ A relevant disease in this scenario is acute myocardial infarction, resulting from insufficient transport of blood to the heart, caused mainly by coronary heart disease. Myocardial infarction leads to ventricular remodeling, fibrosis, necrosis, heart failure, among others, which may cause partial or total cardiac dysfunction. ${ }^{(2)}$ Considering the several disadvantages of heart transplantation, which is still the best option for patients with end-stage heart failure, ${ }^{(3)}$ and the restricted regenerative abilities of cardiomyocytes to heal the heart after an acute acute myocardial infarction, ${ }^{(4)}$ many studies in regenerative medicine have been performed creating alternatives for myocardial regeneration through tissue engineering.

Tissue engineering is a set of biomedical, biotechnological and engineering techniques that aim to maintain, regenerate or replace tissues or organs. Advances in tissue engineering are evident, and the application of this technology to the regeneration of myocardium has been increasingly explored, and presented encouraging results. The main approach of this scientific field is the creation of scaffolds, which contain cells that can be applied as cardiac grafts in the body, to have the desired recovery.

This review briefly presents the most widely used techniques in cardiac tissue engineering spanning two decades: from the late 1990s, when this tissue engineering application saw its first studies, to nowadays, when grafts with a broad potential for cardiac regeneration are sought.

\section{CARDIAC GRAFTS}

The techniques used to obtain cardiac grafts focus on four important issues (Figure 1): (1) scaffold material selection; (2) scaffold material production; (3) cell selection; and (4) in vitro cell culture.

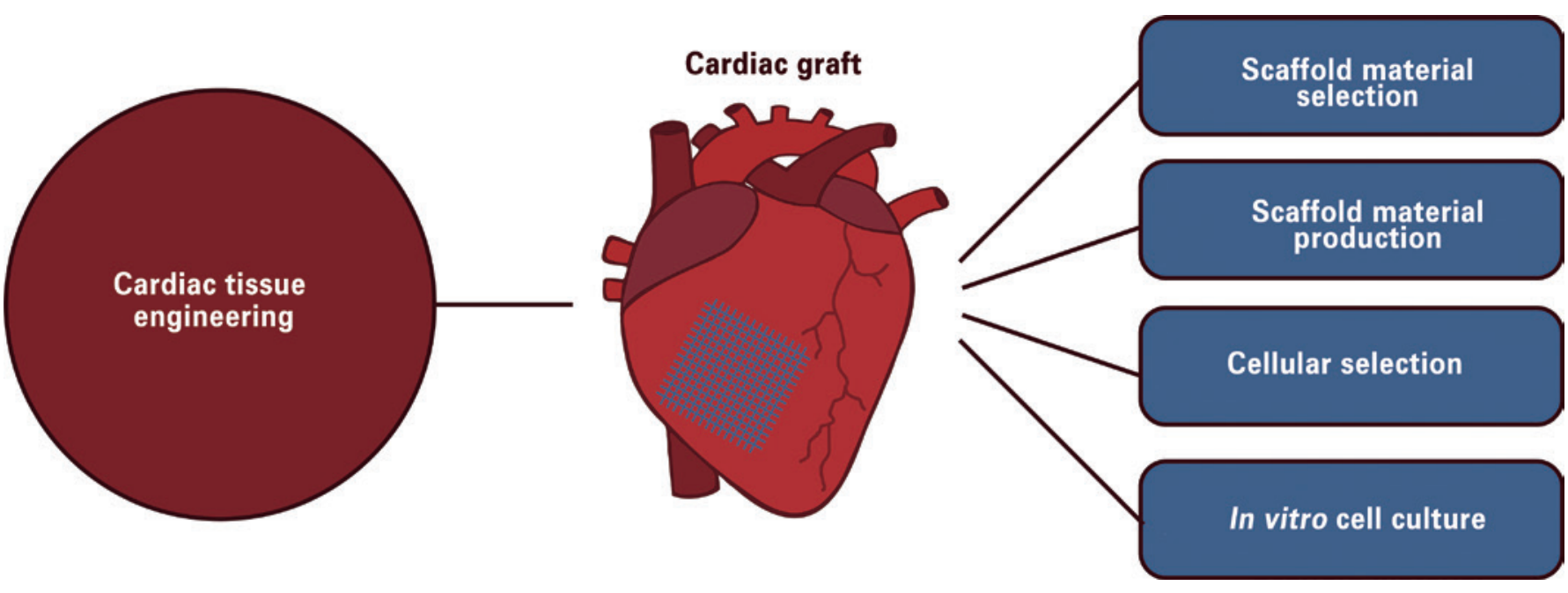

Source: Private collection.

Figure 1. Cardiac graft engineering techniques

\section{Scaffold material selection}

Biomaterials have been the focus of materials for use in tissue engineering, as traditional biomaterials or development of tissue engineering-specific variants. The approach usually taken into account is since biomaterials are able to positively interact with biological systems, they should then seek to improve the regeneration of the damaged tissue or effectively replacing it.

One of the most important classes of biomaterials comprises polymers, which are available with different 
compositions and properties. Polymers are the most used biomaterials for cardiac regeneration, and this class of materials may be divided into synthetic and natural polymers, in addition to synthetic/natural combination materials. ${ }^{(5)}$

Some synthetic biopolymers that have been used for myocardial tissue engineering include polyglycolic acid (PGA), ${ }^{(6)}$ polylactic-l-acid (PLLA), polylactic glycolic acid (PLGA) and polyurethane. This review focuses on the application of polyurethane in cardiac tissue engineering, considering that this biopolymer is one of the most used.

There is a variety of biomedical applications for PU, from durable devices to biodegradable scaffolds. ${ }^{(7,8)}$ Considering its good tissue and blood compatibility, cell adhesion and ductility properties, ${ }^{(9)}$ polyurethane has been investigated as an alternative for vascular grafts $^{(10)}$ and other medical devices. However, long-term biostability has proved to be an obstacle for this type of application. ${ }^{(10)}$

In contrast, cardiac tissue engineering strategies focus on temporary polymer scaffolds with adjustable degradation rates, good porosity, biocompatibility and elastomeric properties, which can mechanically favor the tissue contraction inherent to the cardiac function. These properties are met in polyurethane-based scaffolds ${ }^{(11)}$ (Figure 2), and different approaches using polyurethane have therefore been investigated, demonstrating the different possibilities and the versatility of polyurethane as a material for porous scaffolds in myocardial regeneration. Fujimoto et al., published a successful animal trial using a biodegradable, porous polyurethane heart patch that promoted a contractile phenotype,

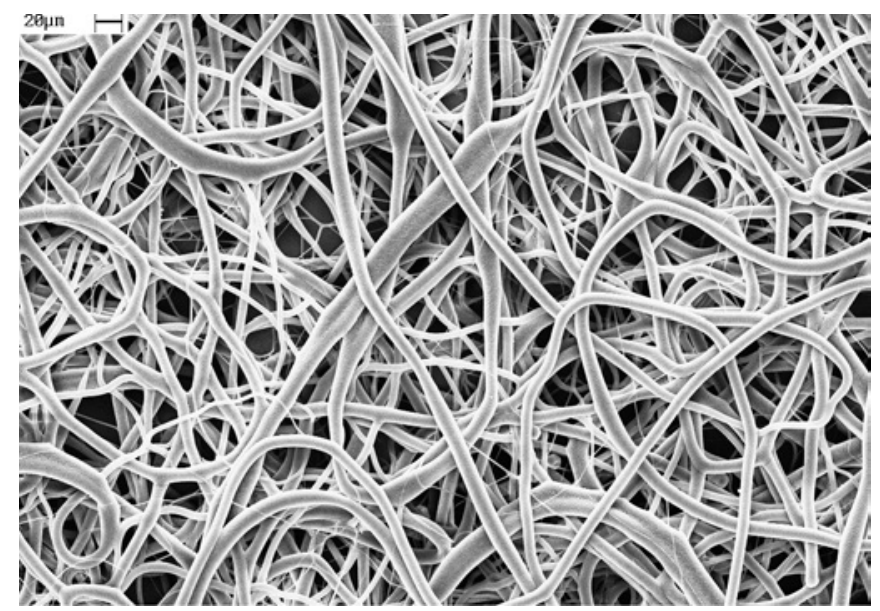

Figure 2. Scanning electron microscopy of electrospun polyurethane-based scaffold. Scale bar: $20 \mu \mathrm{m}$ smooth muscle tissue formation and improved cardiac remodeling and contractile function at the chronic stage. ${ }^{(12)}$ Baheiraei et al., demonstrated the synthesis of a novel conductive, biodegradable polyurethane containing oligoaniline, as an electroactive conductive polymer in cell culture experiments. ${ }^{(13)}$

Natural polymers for scaffolds are inspired by the extracellular matrix (ECM) that holds the cells together in a native tissue. Therefore, some materials, such as collagen (mainly type I and III are found in the heart) and fibrin, have been extensively investigated in cardiac tissue engineering for their properties of natural interaction with cells. ${ }^{(14,15)}$ However, the mechanical properties of these materials, depending on the conformation in the form of gels or more solid structures, can be poor and not compatible with the cardiac tissue. ${ }^{(5)}$ One recent strategy to obtain natural polymers with a suitable size and shape (anatomy) is decellularization.

Considering the often poor mechanical characteristics of natural polymers, the combination of synthetic and natural polymers has been proposed to improve the weakness of each material to create a scaffold with better properties. Alperin et al., showed that embryonic stem cell-derived cardiomyocytes could be seeded on polyurethane films coated with collagen IV and laminin, demonstrating a higher number of contracting films than polyurethane without coating. ${ }^{(16)}$ Hong et al., generated a biohybrid composite combining ECM with polyurethane to improve bioactivity in vivo, and employed an electrospinning/electrospray method. ${ }^{(17)}$ Therefore, a promising approach for cardiac regeneration can be, for example, the synthesis of collagen-based polyurethane.

\section{Scaffold material production}

An important issue that has been the object of investigation for groups involved in tissue engineering of the myocardium is the delivery method of the cells to the damaged site. One of the first technologies developed for cardiac regeneration was cellular cardiomyoplasty. This technology was very important for the study of cell types, their application and effects in cardiac regeneration. However, the delivery methods of the cells in the myocardial tissue used in this technology, such as the transvenous, endomyocardial and intracoronary routes, have not proven themselves satisfactory and had many disadvantages leading to inefficiencies. ${ }^{(18)}$ Thus, other cardiac tissue engineering strategies have been planned to improve the results of cardiac regeneration, including injectable biomaterials containing cells, ${ }^{(19)}$ and the creation of two or three-dimensional porous structures (patch or scaffold). 
Many techniques have been investigated in order to create grafts to be implanted in the heart, and include fiber production methods, such as electrospinning ${ }^{(7,8,20)}$ and rotary-jet spinning, ${ }^{(21)}$ as well as cell-sheet engineering. ${ }^{(22)}$ Besides that, the most interesting and recent approaches are techniques, such as decellularization, aiming to obtain three-dimensional structures that not only may regenerate the existing heart, but be used to create an entire bioartificial organ.

Decellularization is a process that consists of removing all cells from tissues or organs and maintaining the ECM intact (Figure 3), through different physical, chemical and enzymatic methods. This technique is widely used to obtain biologic scaffolds for clinical applications. The process of perfusion decellularization has been shown to be efficient in preserving the threedimensional geometry of organs while eliminating the cells with a more even distribution of decellularization agents. ${ }^{(23,24)}$ This technique has been the most widely used for whole heart bioengineering, owing in part to the anatomical complexity of the macro and microanatomy of the heart organ, difficult to reproduce in detail by $100 \%$ synthetic means, but reasonably feasible through the decellularization approach. The choice of conduit for the perfusate is also important, and different conduits of vascular or parenchymal nature are viable alternatives for certain organs (e.g., kidney-vascular: renal artery, renal vein; parenchymal: ureter), but for heart decellularization, the vascular perfusion route is preferred, presenting promising results. ${ }^{(24)}$

\section{Cellular selection}

The cellular cardiomyoplasty technology is based on cell transplantation, consisting of supplying cells to the injured myocardial tissue aiming for the regeneration of the cardiac function that has been compromised. ${ }^{(25)}$ Many cell types have been used for cell transplantation into injured myocardium and are the same used as candidates in other myocardial tissue engineering approaches, including adult, fetal and neonatal cardiomyocytes, ${ }^{(26,27)}$ skeletal myoblasts, ${ }^{(28)}$ bone marrow derived stem cells (such as mesenchymal, endothelial and hematopoietic stem/ progenitor cells), ${ }^{(29)}$ embryonic stem cells, ${ }^{(30-33)}$ smooth muscle cells, ${ }^{(34,35)}$ adipose tissue derived stem cells, ${ }^{(36,37)}$ cardiac stem cells ${ }^{(38)}$ and the relatively novel technology of induced pluripotent stem cells (iPS cells). ${ }^{(39,40)}$ A variety of considerations must be made to choose the best cell type to be used in each situation, depending, e.g., on its availability and convenience. ${ }^{(41)}$ As such, it is valuable to analyze the advantages and disadvantages of each type of cell (Table 1).

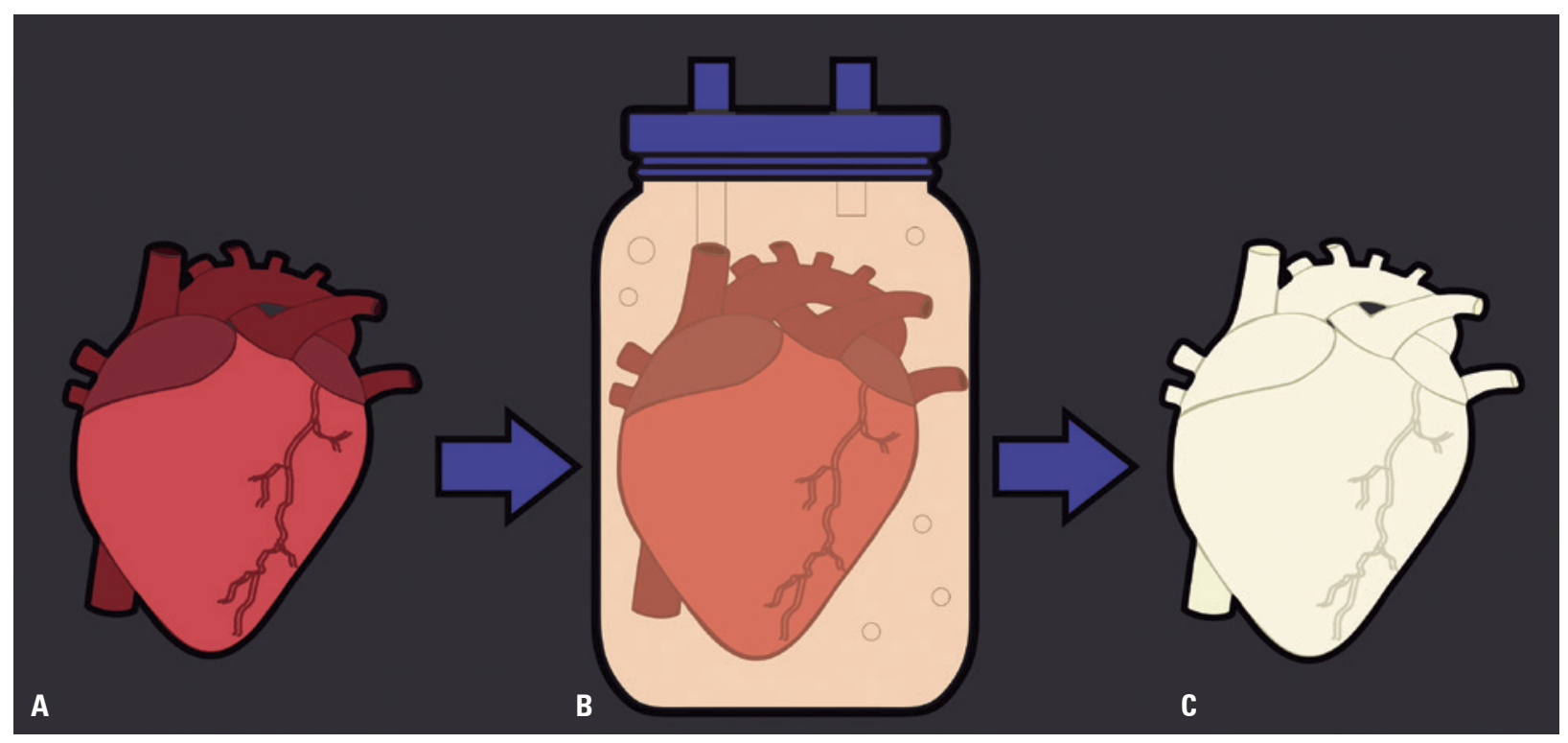

Source: Private collection

Figure 3. Decellularization schematic. (A) whole heart (may be human, e.g. cadaveric or a transplant reject or, more commonly, from an animal donor of suitable size/ anatomy match, often porcine) is placed into $(B)$ an organ chamber of a decellularization bioreactor and appropriately connected up with suitable tubing and cannulae for perfusion, and the decellularization process initiated. Over a period of time, usually 1 or more days of continuous application of decellularization solution, the heart gradually whitens, indicative of the cell constituent of the tissue being washed away, largely leaving behind the collagen and other connective tissue substance and preserving to a great extent the original organs anatomical architecture with respect to vasculature and parenchyma (C) 
Table 1. Advantages and disadvantages of each type of cell used for cellular cardiomyoplasty

\begin{tabular}{|c|c|c|c|}
\hline Cell type & Mechanism of action & Advantages & Disadvantages \\
\hline $\begin{array}{l}\text { Cardiomyocytes (adult, fetal and } \\
\text { neonatal) }\end{array}$ & Myogenesis & $\begin{array}{l}\text { Integration with the host tissue, as seen in rodents }{ }^{26,27 \mid} \\
\text { Adult cardiomyocytes' phenotype }{ }^{26 \mid}\end{array}$ & $\begin{array}{c}\text { Ethics dilemma } \\
\text { Inability to reproduce }{ }^{(25)} \\
\text { Limited availability } \\
\text { Immunogenicity } \\
\text { Short cell survival }{ }^{(25)} \\
\text { Poor integration with host tissue in porcine }{ }^{(27)}\end{array}$ \\
\hline Skeletal myoblasts & Myogenesis & $\begin{array}{l}\text { Autologous } \\
\text { High cell survival and engraftment }{ }^{(42)} \\
\text { Adult skeletal muscle phenotype }{ }^{(28)} \\
\text { Easy to isolate }\end{array}$ & $\begin{array}{c}\text { High risk of arrhythmias } \\
\text { Low structural and physiological integration with } \\
\text { host tissue }\end{array}$ \\
\hline $\begin{array}{l}\text { Bone marrow-derived stem } \\
\text { cells (mesenchymal stem cells, } \\
\text { endothelial progenitor cells, } \\
\text { hematopoietic stem cells) }\end{array}$ & & $\begin{array}{c}\text { Multipotent } \\
\text { Autologous } \\
\text { Easy to isolate } \\
\text { High expansion potential } \\
\text { Presence of paracrine effects }{ }^{(43)}\end{array}$ & $\begin{array}{l}\text { Possible angiogenesis at unwanted sites }{ }^{(41)} \\
\text { Limited availability }\end{array}$ \\
\hline Mesenchymal stem cells & Myogenesis & $\begin{array}{l}\text { Differentiate into cardiomyocytes-like phenotype }{ }^{(44)} \\
\text { Differentiation into endothelial cells as seen in canines } \\
\qquad \text { Immunosuppressive properties }{ }^{(46)} \\
\text { High structural and physiological integration with host } \\
\text { tissule }{ }^{(43,45)}\end{array}$ & $\begin{array}{l}\text { Immunogenicity of allogenous mesenchymal } \\
\text { stem cells } s^{\langle 4\rangle}\end{array}$ \\
\hline Endothelial progenitor cells & Angiogenesis & Neovasculogenesis ${ }^{(48)}$ & $\begin{array}{l}\text { Limitations in number and migration of cells in } \\
\text { patients with coronary artery disease }\end{array}$ \\
\hline Hematopoietic stem cells & Angiogenesis & $\begin{array}{l}\text { Beneficial impact on left ventricular remodeling and } \\
\text { angiogenesis }{ }^{(50)}\end{array}$ & Incapable of differentiating into cardiomyocytes ${ }^{(50)}$ \\
\hline Embryonic stem cells & Myogenesis & $\begin{array}{c}\text { High proliferation }^{(51)} \\
\text { Pluripotent }{ }^{(51)} \\
\text { Differentiate into cardiomyocytes } \\
\text { Can be pre-treated with pro-survival factors }{ }^{(33)}\end{array}$ & $\begin{array}{l}\text { Ethical dilemma } \\
\text { Risk of teratoma formation }{ }^{(51)} \\
\text { High immunogenicity } \\
\text { Limited availability }\end{array}$ \\
\hline Smooth muscle cells & Myogenesis & Elastic properties improve heart function ${ }^{(35)}$ & $\begin{array}{l}\text { Immunogenicity }{ }^{(34)} \\
\text { Do not improve contractile function }{ }^{(34)}\end{array}$ \\
\hline Adipose tissue-derived stem cells & $\begin{array}{l}\text { Angiogenesis } \\
\text { Myogenesis }\end{array}$ & $\begin{array}{c}\text { Multipotent(53) } \\
\text { High availability } \\
\text { Easy to isolate }{ }^{(53)} \\
\text { High proliferation }{ }^{(36)} \\
\text { Secrete growth factors }{ }^{(37)} \\
\text { Induce myogenesis and angiogenesis }{ }^{(37)}\end{array}$ & $\begin{array}{l}\text { Poor long-term cell engraftment }{ }^{(54)} \\
\text { No significant differentiation }{ }^{(55)}\end{array}$ \\
\hline Cardiac stem cells & Myogenesis & $\begin{array}{l}\text { Autologous } \\
\text { Multipotent }{ }^{(38)} \\
\text { Expand in vitro }\end{array}$ & Limited availability \\
\hline Induced pluripotent stem cells & Myogenesis & $\begin{array}{c}\text { Pluripotent } \\
\text { Autologous } \\
\text { Differentiate into cardiomyocytes }{ }^{(39)} \\
\text { Good availability } \\
\text { High expansion potential }\end{array}$ & Risk of teratoma formation ${ }^{(40)}$ \\
\hline
\end{tabular}

\section{In vitro cell culture}

The next topic critical for creating a cardiac graft, following cellular selection, is the cell culture. From dishes to specialized cell culture facilities (bioreactors), research has been made to study how to promote cell proliferation, alignment, differentiation and maturation in vitro, before the implantation in vivo.
The potential for alignment of cells on the scaffold has been shown in some studies with polyurethane and in vitro cell culture in dishes. McDevitt et al., demonstrated that cardiomyocytes could be cultured on polyurethane films with printed laminin patterns, allowing the two-dimensional alignment of cells and presenting contractile response. ${ }^{(11)}$ Rockwood et 
al., prepared aligned and unaligned biodegradable polyurethane culture substrates using electrospinning, demonstrating that aligned scaffolds can generate a cellular organization similar to cardiac native tissue. ${ }^{(20)}$

To promote increased cellular proliferation, differentiation and maturation, the in vitro cell culture of the chosen cell types is performed in specialized cell culture facilities, be it in academia or industry. The standard infrastructure comprises clean rooms, carbon dioxide incubators, biological safety cabinets, sterile cell culture consumables, cell counters, and other standard equipment. In some cases, ${ }^{(56)}$ it may be warranted the use of cell bioreactors, based solely on the purpose of improving, refining and optimizing the quality and yield (expansion) of the cell itself. The objective of employing such cell bioreactors, that could include instruments such as wave bioreactors (GE Xuri, GE Healthcare, New York, NY, USA) and stirred tank bioreactors (Applikon, Delft, The Netherlands; Sartorius, Göttingen, Germany; and others) with microcarriers for adherent cell culture, or automated cell culture robots (SelecT \& CompacT SelecT, Sartorius Stedim Biotech, Royston, United Kingdom; VANTAGE \& STAR systems, Hamilton, Reno, NV, USA; Freedom EVO system, Tecan, Männedorf, Switzerland; Cytomat 10 system, Thermo Fisher, Waltham, MA, USA; and others) would be improving on the quality and yield feasibly attainable by traditional cell culture approaches. Looking more broadly on the instrument category as a whole, bioreactors may be described as systems with controlled conditions and parameters that enable the stimulation of cell growth or biotransformation of substrate into products of interest by living cells or its components, such as enzymes or organelles. ${ }^{(56)}$ Systems based on the production of bioproducts, such as proteins, lipids, among others, are called production bioreactors. ${ }^{(57)}$ Systems that instead focus on cell expansion and cell therapy, in order to have these cells as the output are called cell bioreactors. ${ }^{(57)}$ Lastly, systems used for tissue engineering, seeking to obtain mature tissue as an output, are called tissue bioreactors. ${ }^{(57)}$

Many types of bioreactors have been used for different applications in bioprocesses. The diversity of bioreactor design alternatives is based on specific parameters and conditions, such as heat or gas transfer and homogeneity, required for each application. Some examples of bioreactor designs are the stirred tank and the airlift reactors. ${ }^{(58)}$

The possibility of creating a dynamic environment with mechanical, physical and biochemical control makes tissue bioreactors a widely used technology in tissue engineering, due to the necessity of providing suitable stimuli for appropriate cellular differentiation and proliferation, and ECM properties for a tissue in development. ${ }^{(59)}$ Some studies in bioreactors for tissue engineering include bone, ${ }^{(60)}$ cartilage $^{(61)}$ and cardiovascular system. ${ }^{(62)}$

Cardiovascular tissue engineering studies applying bioreactors involve blood vessels, ${ }^{(63)}$ heart valves ${ }^{(57,64)}$ and cardiac tissue culture. ${ }^{(4,65-68)}$ Cardiac tissue is extremely complex and bioreactors may help to better understand the influence of each parameter during the in vitro culture (Figure 4). Carrier et al., studied and characterized the effect of varying different parameters, such as cell source, cell seeding, flow and oxygen on cardiac tissue engineering structure and function, seeding well-mixed suspensions of cardiomyocytes in orbitally mixed dishes and spinner flasks. ${ }^{(65)}$ Bursac et al., demonstrated that three-dimensional cardiac muscle could be engineered using isolated cells and biodegradable polymer (PGA) scaffolds, on spinner flasks, to obtain specific structural and electrophysiological properties. ${ }^{(6)}$ Papadaki et al., showed the correlation between molecular, structural and electrophysiological properties, and how they can be improved using a high concentration of myocytes, laminin-coated surface-hydrolyzed PGA scaffolds, using rotating bioreactors and a low-serum medium. ${ }^{(4)}$ Carrier et al., also studied the effect of perfusion on improving the transport conditions of the culture, and creating constructs with relatively uniform spatial distributions of cardiac cells, using mixed flasks. ${ }^{(66)}$ Radisic et al., demonstrated that rapid gel-cell inoculation, followed by immediate perfusion, enabled fast and uniform seeding of cardiomyocytes in a high density whilst maintaining cell viability. ${ }^{(67)}$ Bursac et al., showed that neonatal rat cardiomyocytes cultured using rotating bioreactors in three-dimensional scaffolds had properties more similar to native tissue than cells cultured in monolayers. ${ }^{(68)}$ Gonen-Wadmany et al., studied the effect of a strain stimulation bioreactor to apply cyclic distension on engineered cardiac constructs, and improve cellular orientation in vitro. ${ }^{(69)}$ Lichtenberg et al., reported the development of a multifunctional bioreactor with four chambers and two separated compartments for three-dimensional co-cultivation of different cell types and culture conditions. ${ }^{(70)}$ As is apparent, many types of bioreactors have been designed for cardiac tissue engineering and the different approaches tested have paved the way for a large number of possible strategies, which may be improved, refined or optimized to obtain an ideal graft of mature myocardial tissue. 


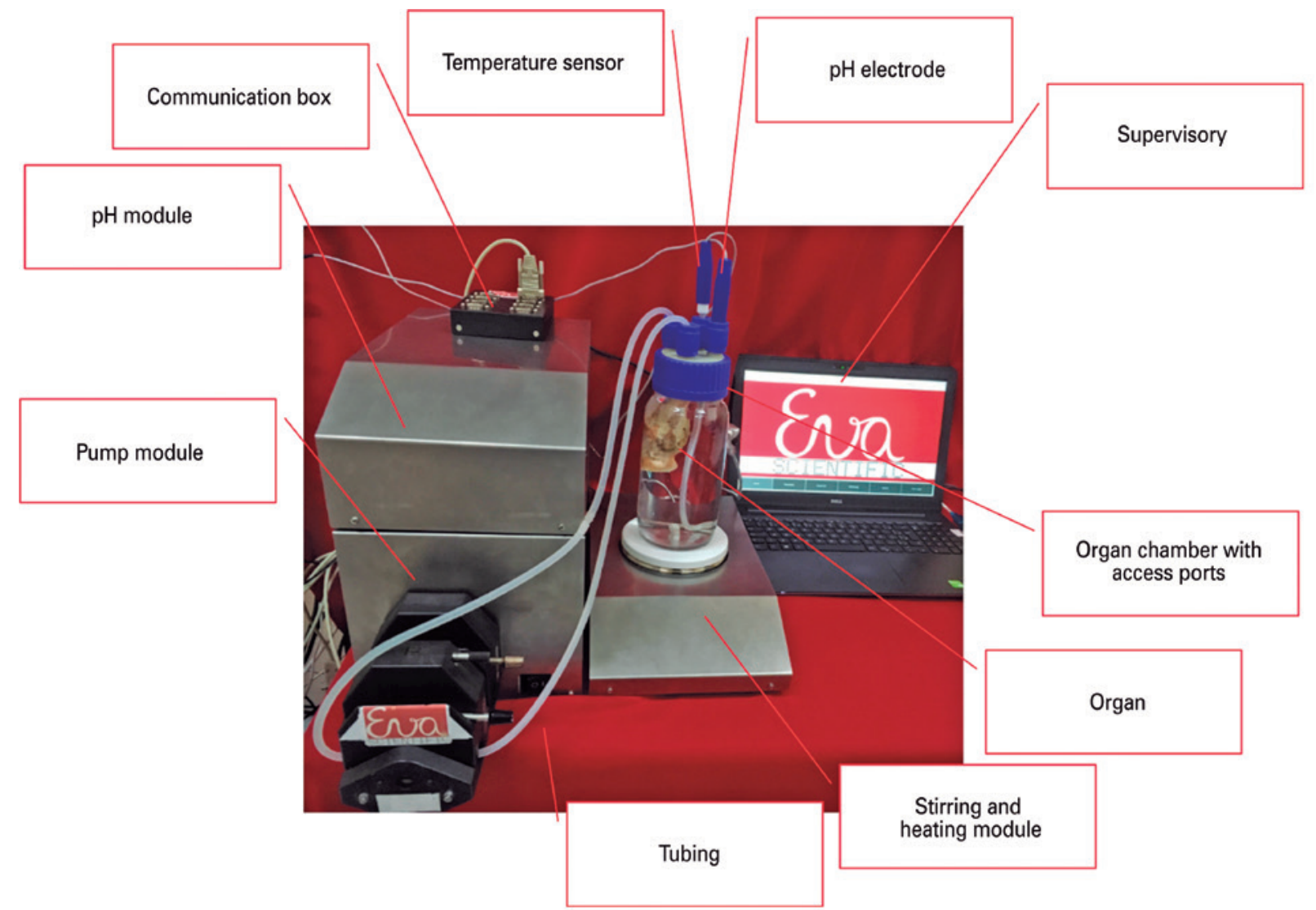

Source: Private collection.

Figure 4. Eva Luxor ${ }^{\top \mathrm{M}}$ bioreactor for tissues and organs with a trachea in the organ chamber, undergoing a decellularization process. The same bioreactor may be employed for tissue cultivation, using cell culture media instead of decellularization solutions (e.g., detergents)

\section{CONCLUSIONS AND PERSPECTIVES}

The heart is an extremely complex organ and the techniques influencing its regeneration depend on many variables of non-trivial character. These techniques generally focus on the scaffold material selection, scaffold material production, cellular selection and cellular cultivation in vitro. Many studies in this field have already made enormous progress, either looking for a graft or an entire bioartificial heart. However, much work remains to be done to better understand and solve the challenges of experimental technologies, improving on existing techniques and developing new techniques, protocols and methods.

For the material selection and structure, firstly, it is important to define the best material (synthetic, natural or hybrid) for cardiac applications. Some desired properties for these materials are adjustable degradation rates, good porosity, biocompatibility, hemocompatibility, good cell adhesion, mechanical and elastic properties compatible with the heart, and that the material permits an electrical coupling between cells and between the scaffold and the native tissue..$^{(11,13)}$ Secondly, it is necessary to choose the technique to produce the scaffold in which cells are going to be seeded before the implantation. Future perspectives in this field focus on obtaining a scaffold from the threedimensional structure of an entire heart. In addition to decellularization, which is promising for cardiac tissue engineering application, another technology in vogue is three-dimensional bioprinting of tissues and organs. ${ }^{(71)}$ The combination of three-dimensional bioprinting, bioreactors and stem cells could provide for a novel enabling technology for the development of the next-generation human organ.

For cell selection and expansion in vitro, the first essential step is to determine the best cell type for the application (bone marrow-derived stem cells, cardiomyocytes, iPSC, among others), considering the availability and concerns about each cell type. After that, the cultivation of these cells in vitro is needed before seeding and subsequent tissue implantation. The most efficient technology to provide the proliferation and differentiation of these cells is the bioreactor. 
Many different types of bioreactors for cardiac tissue engineering applications have been studied, but it remains to be determined what approaches are the most suitable, with an ideal balance of advantages and disadvantages, appreciating that no single approach may tick all boxes.

Other opportunities for myocardial tissue engineering include finding the best combination of different techniques described herein, to achieve an ideal bioengineered myocardium for clinical applications and to study the influence of other aspects, such as the best period of time for implantation, with increased engraftment of cells at the recipient's tissue, after an acute myocardial infarction. ${ }^{(18)}$

\section{ACKNOWLEDGMENTS}

This work was supported by the Instituto Nacional de Ciência e Tecnologia em Biofabricação (INCTBIOFABRIS), Conselho Nacional de Desenvolvimento Científico e Tecnológico (CNPq, process 573661/2008-1) and Fundação de Amparo à Pesquisa do Estado de São Paulo (FAPESP, processes 2008/57860-3 and 2014/22799-3).

\section{AUTHORS' INFORMATION}

Rodrigues IC: https://orcid.org/0000-0003-3874-2387

Kaasi A: https://orcid.org/0000-0002-2440-5593

Maciel Filho R: https://orcid.org/0000-0001-6511-7283

Jardini AL: https://orcid.org/0000-0002-9381-9335

Gabriel LP: https://orcid.org/0000-0003-4035-5626

\section{REFERENCES}

1. World Health Organization (WHO). World Health Statistics 2017: monitoring health for the SDGs [Internet]. Geneva: WHO; 2017 [cited 2018 May 7]. Available from: http://www.who.int/gho/publications/world_health_statistics/ 2017/en/

2. See F, Kompa A, Martin J, Lewis DA, Krum H. Fibrosis as a therapeutic target post-myocardial infarction. Curr Pharm Des. 2005;11(4):477-87. Review.

3. Mangini S, Alves BR, Silvestre OM, Pires PV, Pires LJ, Curiati MN, et al. Heart transplantation: review. einstein (São Paulo). 2015;13(2):310-8. Review.

4. Papadaki M, Bursac N, Langer R, Merok J, Vunjak-Novakovic G, Freed LE. Tissue engineering of functional cardiac muscle: molecular, structural, and electrophysiological studies. Am J Physiol Heart Circ Physiol. 2001;280(1): H168-78.

5. Chen QZ, Harding SE, Ali NN, Lyon AR, Boccaccini AR. Biomaterials in cardiac tissue engineering: ten years of research survey. Mater Sci Eng Rep. 2008; 59(1-6):1-37.

6. Bursac N, Papadaki M, Cohen RJ, Schoen FJ, Eisenberg SR, Carrier R, etal. Cardiac muscle tissue engineering: toward an in vitro model for electrophysiological studies. Am J Physiol. 1999;277(2 Pt 2):H433-44.

7. Gabriel LP, Rodrigues AA, Macedo M, Jardini AL, Maciel Filho R. Electrospun polyurethane membranes for Tissue Engineering applications. Mater Sci Eng C. 2017:72:113-7.
8. Gabriel LP, Rodrigues AA, Jardini AL, Maciel Filho R. From biodegradable to long-term polyurethanes: in vitro fibroblasts adhesion and degradation study of electrospun polyurethane membranes. Int J Eng Res Appl. 2016;6(7):13-9.

9. Bos GW, Poot AA, Beugeling T, van Aken WG, Feijen J. Small-diameter vascular graft prostheses: current status. Arch Physiol Biochem. 1998;106(2):100-15. Review.

10. Zhang Z, King MW, Marois Y, Marois M, Guidoin R. In vivo performance of the polyesterurethane Vascugraft prosthesis implanted as a thoraco-abdominal bypass in dogs: an exploratory study. Biomaterials. 1994;15(13):1099-112.

11. McDevitt TC, Woodhouse KA, Hauschka SD, Murry CE, Stayton PS. Spatially organized layers of cardiomyocytes on biodegradable polyurethane films for myocardial repair. J Biomed Mater Res A. 2003;66(3):586-95.

12. Fujimoto KL, Tobita K, Merryman WD, Guan J, Momoi N, Stolz DB, et al. An elastic, biodegradable cardiac patch induces contractile smooth muscle and improves cardiac remodeling and function in subacute myocardial infarction. J Am Coll Cardiol. 2007;49(23):2292-300.

13. Baheiraei N, Yeganeh H, Ai J, Gharibi R, Azami M, Faghihi F. Synthesis, characterization and antioxidant activity of a novel electroactive and biodegradable polyurethane for cardiac tissue engineering application. Mater Sci Eng C. 2014;44:24-37.

14. Eschenhagen T, Fink C, Remmers U, Scholz H, Wattchow J, Weil J, et al. Three-dimensional reconstitution of embryonic cardiomyocytes in a collagen matrix: a new heart muscle model system. FASEB J. 1997;11(8):683-94.

15. Christman KL, Fok HH, Sievers RE, Fang Q, Lee RJ. Fibrin glue alone and skeletal myoblasts in a fibrin scaffold preserve cardiac function after myocardial infarction. Tissue Eng. 2004;10(3-4):403-9.

16. Alperin C, Zandstra PW, Woodhouse KA. Polyurethane films seeded with embryonic stem cell-derived cardiomyocytes for use in cardiac tissue engineering applications. Biomaterials. 2005;26(35):7377-86.

17. Hong Y, Huber A, Takanari K, Amoroso NJ, Hashizume R, Badylak SF, et al. Mechanical properties and in vivo behavior of a biodegradable synthetic polymer microfiber-extracellular matrix hydrogel biohybrid scaffold. Biomaterials. 2011;32(13):3387-94.

18. Wang F, Guan J. Cellular cardiomyoplasty and cardiac tissue engineering for myocardial therapy. Adv Drug Deliv Rev. 2010;62(7-8):784-97. Review.

19. Ungerleider JL, Christman KL. Concise review: injectable biomaterials for the treatment of myocardial infarction and peripheral artery disease: translational challenges and progress. Stem Cells Transl Med. 2014;3(9):1090-9. Review.

20. Rockwood DN, Akins RE Jr, Parrag IC, Woodhouse KA, Rabolt JF. Culture on electrospun polyurethane scaffolds decreases atrial natriuretic peptide expression by cardiomyocytes in vitro. Biomaterials. 2008;29(36):4783-91.

21. Cardoso GB, Machado-Silva AB, Sabino M, Santos AR Jr, Zavaglia CA. Novel hybrid membrane of chitosan/poly ( $\varepsilon$-caprolactone) for tissue engineering. Biomatter. 2014;4(1):e29508.

22. Shimizu T, Yamato M, Kikuchi A, Okano T. Cell sheet engineering for myocardial tissue reconstruction [Review]. Biomaterials. 2003;24(13):2309-16.

23. Tapias LF, Ott HC. Decellularized scaffolds as a platform for bioengineered organs. Curr Opin Organ Transplant. 2014;19(2):145-52. Review.

24. Keane TJ, Swinehart IT, Badylak SF. Methods of tissue decellularization used for preparation of biologic scaffolds and in vivo relevance. Methods. 2015;84:25-34. Review.

25. Taylor DA. Cell-based myocardial repair: how should we proceed? Int Cardiol. 2004;95 Suppl 1:S8-12. Review.

26. Soonpaa MH, Koh GY, Klug MG, Field LJ. Formation of nascent intercalated disks between grafted fetal cardiomyocytes and host myocardium. Science. 1994;264(5155):98-101.

27. Li RK, Weisel RD, Mickle DA, Jia ZO, Kim EJ, Sakai T, et al. Autologous porcine heart cell transplantation improved heart function after a myocardia infarction. J Thorac Cardiovasc Surg. 2000;119(1):62-8.

28. Murry CE, Wiseman RW, Schwartz SM, Hauschka SD. Skeletal myoblast transplantation for repair of myocardial necrosis. J Clin Invest. 1996;98(11): 2512-23. 
29. Janssens S, Dubois C, Bogaert J, Theunissen K, Deroose C, Desmet W, et al. Autologous bone marrow-derived stem-cell transfer in patients with ST-segment elevation myocardial infarction: double-blind, randomised controlled trial. Lancet. 2006;367(9505):113-21.

30. Klug MG, Soonpaa MH, Koh GY, Field LJ. Genetically selected cardiomyocytes from differentiating embronic stem cells form stable intracardiac grafts. J Clin Invest. 1996;98(1):216-24.

31. Kehat I, Kenyagin-Karsenti D, Snir M, Segev H, Amit M, Gepstein A, et al. Human embryonic stem cells can differentiate into myocytes with structural and functional properties of cardiomyocytes. J Clin Invest. 2001;108(3):407-14.

32. Kehat I, Khimovich L, Caspi O, Gepstein A, Shofti R, Arbel G, et al. Electromechanical integration of cardiomyocytes derived from human embryonic stem cells. Nat Biotechnol. 2004;22(10):1282-9.

33. Laflamme MA, Chen KY, Naumova AV, Muskheli V, Fugate JA, Dupras SK, et al. Cardiomyocytes derived from human embryonic stem cells in pro-survival factors enhance function of infarcted rat hearts. Nat Biotechnol. 2007; 25(9):1015-24.

34. Li RK, Jia ZQ, Weisel RD, Merante F, Mickle DA. Smooth muscle cell transplantation into myocardial scar tissue improves heart function. J Mol Cell Cardiol. 1999;31(3):513-22.

35. Yoo KJ, Li RK, Weisel RD, Mickle DA, Li G, Yau TM. Autologous smooth muscle cell transplantation improved heart function in dilated cardiomyopathy. Ann Thorac Surg. 2000;70(3):859-65.

36. Planat-Benard V, Silvestre JS, Cousin B, André M, Nibbelink M, Tamarat $\mathrm{R}$, et al. Plasticity of human adipose lineage cells toward endothelial cells: physiological and therapeutic perspectives. Circulation. 2004;109(5):656-63.

37. Rehman J, Traktuev D, Li J, Merfeld-Clauss S, Temm-Grove CJ, Bovenkerk JE, et al. Secretion of angiogenic and antiapoptotic factors by human adipose stromal cells. Circulation. 2004;109(10):1292-8.

38. Barile L, Chimenti I, Gaetani R, Forte E, Miraldi F, Frati G, et al. Cardiac stem cells: isolation, expansion and experimental use for myocardial regeneration. Nat Clin Pract Cardiovasc Med. 2007;4(S1 Suppl 1):S9-14.

39. Zwi L, Caspi O, Arbel G, Huber I, Gepstein A, Park IH, et al. Cardiomyocyte differentiation of human induced pluripotent stem cells. Circulation. 2009; 120(15):1513-23

40. Nelson TJ, Martinez-Fernandez A, Yamada S, Perez-Terzic C, Ikeda Y, Terzic A. Repair of acute myocardial infarction by human stemness factors induced pluripotent stem cells. Circulation. 2009;120(5):408-16.

41. Ott HC, McCue J, Taylor DA. Cell-based cardiovascular repair-the hurdles and the opportunities. Basic Res Cardiol. 2005;100(6):504-17.

42. Reinlib L, Field L. Cell transplantation as future therapy for cardiovascular disease?: a workshop of the National Heart, Lung, and Blood Institute. Circulation. 2000;101(18):E182-7.

43. Uemura R, Xu M, Ahmad N, Ashraf M. Bone marrow stem cells prevent left ventricular remodeling of ischemic heart through paracrine signaling. Circ Res. 2006;98(11):1414-21.

44. Toma C, Pittenger MF, Cahill KS, Byrne BJ, Kessler PD. Human mesenchymal stem cells differentiate to a cardiomyocyte phenotype in the adult murine heart. Circulation. 2002;105(1):93-8.

45. Silva GV, Litovsky S, Assad JA, Sousa AL, Martin BJ, Vela D, et al. Mesenchymal stem cells differentiate into an endothelial phenotype, enhance vascular density, and improve heart function in a canine chronic ischemia model. Circulation. 2005;111(2):150-6.

46. Mangi AA, Noiseux $N$, Kong $D$, He $H$, Rezvani $M$, Ingwall JS, et al. Mesenchymal stem cells modified with Akt prevent remodeling and restore performance of infarcted hearts. Nat Med. 2003;9(9):1195-201.

47. Huang XP, Sun Z, Miyagi Y, McDonald Kinkaid H, Zhang L, Weisel RD, et al. Differentiation of allogeneic mesenchymal stem cells induces immunogenicity and limits their long-term benefits for myocardial repair. Circulation. 2010; 122(23):2419-29.

48. Losordo DW, Dimmeler S. Therapeutic angiogenesis and vasculogenesis for ischemic disease: part II: cell-based therapies. Circulation. 2004;109(22): 2692-7.

49. Vasa M, Fichtlscherer S, Aicher A, Adler K, Urbich C, Martin $H$, et al. Number and migratory activity of circulating endothelial progenitor cells inversely correlate with risk factors for coronary artery disease. Circ Res. 2001:89(1):E1-7

50. Murry CE, Soonpaa MH, Reinecke $H$, Nakajima H, Nakajima HO, Rubart M, et al. Haematopoietic stem cells do not transdifferentiate into cardiac myocytes in myocardial infarcts. Nature. 2004;428(6983):664-8.

51. Thomson JA, Itskovitz-Eldor J, Shapiro SS, Waknitz MA, Swiergiel JJ, Marshal VS, et al. Embryonic stem cell lines derived from human blastocysts. Science. 1998;282(5391):1145-7. Erratum in: Science. 1998;282(5395):1827.

52. Swijnenburg RJ, Tanaka M, Vogel H, Baker J, Kofidis T, Gunawan F, et al. Embryonic stem cell immunogenicity increases upon differentiation after transplantation into ischemic myocardium. Circulation. 2005;112(9 Suppl):I166-72.

53. Zuk PA, Zhu M, Ashjian P, De Ugarte DA, Huang Jl, Mizuno H, et al. Human adipose tissue is a source of multipotent stem cells. Mol Biol Cell. 2002; 13(12):4279-95.

54. Schenke-Layland K, Strem BM, Jordan MC, Deemedio MT, Hedrick MH, Roos $\mathrm{KP}$, et al. Adipose tissue-derived cells improve cardiac function following myocardial infarction. J Surg Res. 2009;153(2):217-23.

55. Rigol M, Solanes N, Farré J, Roura S, Roqué M, Berruezo A, et al. Effects of adipose tissue-derived stem cell therapy after myocardial infarction: impact of the route of administration. J Card Fail. 2010;16(4):357-66.

56. Eibl D, Eibl R. Bioreactors for mammalian cells: general overview. Cell and tissue reaction engineering. Berlin, Heidelberg: Springer; 2009. p. 55-82.

57. Kaasi A, Jardini AL. Bioreactors. In: Hashmi S, editor. Reference Module in Materials Science and Materials Engineering. Oxford: Elsevier; 2016. p. 1-15.

58. Mandenius CF. Challenges for bioreactor design and operation. In: Mandenius CF, editor. Bioreactors: Design, Operation and Novel Applications. Germany: Wiley-VCH; 2016. p. 1-34.

59. Korossis S, Bolland F, Kearney J, Fisher J, Ingham E. Bioreactors in tissue engineering. Topics Tissue Eng. 2005;2(8):1-23.

60. Rauh J, Milan F, Günther KP, Stiehler M. Bioreactor systems for bone tissue engineering. Tissue Eng Part B Rev. 2011;17(4):263-80. Review.

61. Darling EM, Athanasiou KA. Articular cartilage bioreactors and bioprocesses Tissue Eng. 2003;9(1):9-26. Review. Erratum in: Tissue Eng. 2003;9(3):565.

62. Barron V, Lyons E, Stenson-Cox C, McHugh PE, Pandit A. Bioreactors for cardiovascular cell and tissue growth: a review. Ann Biomed Eng. 2003; 31(9):1017-30. Review.

63. Isenberg BC, Williams C, Tranquillo RT. Small-diameter artificial arteries engineered in vitro. Circ Res. 2006;98(1):25-35. Review.

64. Kaasi A, Cestari IA, Stolf NA, Leirner AA, Hassager 0, Cestari IN. A new approach to heart valve tissue engineering: mimicking the heart ventricle with a ventricular assist device in a novel bioreactor. J Tissue Eng Regen Med. 2011;5(4):292-300

65. Carrier RL, Rupnick M, Langer R, Schoen FJ, Freed LE, Vunjak-Novakovic G. Effects of oxygen on engineered cardiac muscle. Biotechnol Bioeng. 2002; 78(6):617-25

66. Carrier RL, Rupnick M, Langer R, Schoen FJ, Freed LE, Vunjak-Novakovic G. Perfusion improves tissue architecture of engineered cardiac muscle. Tissue Eng. 2002;8(2):175-88.

67. Radisic $M$, Euloth $M$, Yang L, Langer R, Freed LE, Vunjak-Novakovic G. High-density seeding of myocyte cells for cardiac tissue engineering. Biotechnol Bioeng. 2003;82(4):403-14.

68. Bursac N, Papadaki M, White JA, Eisenberg SR, Vunjak-Novakovic G, Freed LE. Cultivation in rotating bioreactors promotes maintenance of cardiac myocyte electrophysiology and molecular properties. Tissue Eng. 2003;9(6):1243-53.

69. Gonen-Wadmany M, Gepstein L, Seliktar D. Controlling the cellular organization of tissue-engineered cardiac constructs. Ann N Y Acad Sci. 2004;1015(1):299-311.

70. Lichtenberg A, Dumlu G, Walles T, Maringka M, Ringes-Lichtenberg S, Ruhparwar $A$, et al. A multifunctional bioreactor for three-dimensional cell (co)-culture. Biomaterials. 2005;26(5):555-62.

71. Murphy SV, Atala A. 3D bioprinting of tissues and organs. Nat Biotechnol. 2014;32(8):773-85 